\title{
PRAKTIK PEMBAGIAN WARIS TERHADAP AYAH DAN IBU PADA MASYARAKAT MANDAILING DI KABUPATEN MANDAILING NATAL
}

\author{
Abdul Rahim \\ Dosen Universitas Islam Negeri Sumatera Utara \\ e-mail: Abd.rahim.AR32@gmail.com
}

\begin{abstract}
Abstrak
Penelitian ini menyajikan informasi terkini mengenaianalisis hukum Islam terhadap praktik pembagian waris terhadap ayah dan ibu pada masyarakat Mandailing di Kabupaten Mandaing Natal. Penenlitian ini disajikan dalam bentuk kualitatifdengan pendekatan sosiologi hukum (hukum Islam). Penelitian ini menggunakan hukum Islam (kewarisan hukum Islam)sebagai alat analisis dalam menganalisa data penelitian. Pada akhirnya penelitian ini berkesimpulan bahwa pemahaman dan pelaksanaan hukum waris terhadap ayah dan ibu masyarakat masyarakat Mandailing di Kabupaten Mandailing Natal dengan tidak memberikan hak warisnnya dari harta warisan anaknya yang meninggal dunia, berdasarkan pertimbangan kelangsungan hidup istri dan cucunya, seperti biaya pendidikan dan sebagainya sehingga dengan pertimbangan tersebut harta warisan menjadi hak anak dan istri si mayit. Sesungguhnya semangat pelaksanaan hukum masyarakat muslim masyarakat Mandailing di Kabuapaten Mandailing Natal khususnya dibidang waris adalah semangat kemashlahatan.
\end{abstract}

Katakunci: Waris, Ayah, Ibu,Hukum Islam, Mandailing.

\section{A. Pendahuluan}

Pembagian warisan di lakukan setelah seseorang meninggal dunia, karena ketika seseorang yang akan menghembuskan napasnya penghabisan, maka saat itu terjadi peristiwa hukum yang penting, yaitu penyerahan harta dan hak - hak kebendaan milik si mayit kepada ahli waris, baik sebagai ashab al-furud, 'asabah, dan zaw al-arham, sehingga sebelum terjadinya peristiwa wafat itu belum ada sebutan pewaris, ahli waris maupun harta waris. ${ }^{1}$ Para ulama faridiyun menjelaskan tentang kematian seseorang sehingga mengakibatkan terjadinya waris dengan peristiwa kematian yang bersifat haqiqi ${ }^{2}$, hukmi ${ }^{3}$, dan taqdiri. ${ }^{4}$

\footnotetext{
${ }^{1}$ Roihan A. Rasyid, dalam Departemen Agama, Penyelesaian Perkara Umat Islam di Indonesia, dalam Mimbar Umum, No. 9 thn 1993 (Jakarta: al-Hikmah, 1993), h. 18

${ }^{2}$ Mati haqiqi dapat di pahami sebagai kematian yang terjadi dengan segala sebab yang mengakibatkan ia mati sebagai orang yang pernah hidup. Kematian disini di anggap sebagai h yang biasa dan akan di alami setiap orang.

${ }^{3}$ Mati hukmi merupakan kematian yang dipersangkakan secara yuridis oleh suatu lembaga hukum legal yang menangani perkara yang diajukan kepadanya untuk memintakan keputusan hukum. Istilah hukmi hanya menunjuk sebagai hasil ketetapan lembaga hukum legal yang diminta untuk menilai tentang keberadaan seseorang. Mati taqdiri dapat dipahami sebagai kematian seseorang atas persangkaan yang di anggap mati
} 
Khasanah intelektual ulama klasik, keberadaan seseorang yang dapat dimintakan penetapan putusan hakim dalam kasus mati hukmi, peristiwa seseorang yang di anggap hilang sampai saat persoalaaan kematiannya di perkarakan ke pengadilan orang dimaksud tidak di ketahui kabar keberadan hidup atau matinya (biasa di sebut dengan istilah, mafqud )$^{5}$, dapat pula dimaksudkan terhadap orang yang dalam tawanan musuh yang tidak di ketahui lagi tentang mati dan hidupnya dalam waktu yang lama itu diajukan ke pengadilan untuk di tetapkan keberadaannya (biasa di sebut asir). ${ }^{6}$ Dengan kata lain bahwa pengertian mafqud maupun asir penetapan hukumnya harus berdasarkan yurisdiksi dari suatu lembaga hukum legal.

Hukum kewarisan sebelum Islam sangat dipengaruhi oleh sistem sosial yang di anut oleh masyarakat yang ada. Masyarakat jahiliah menganggap bahwa ahli waris yang berhak memperoleh harta warisan dari keluarganya yang meninggal dunia adalah mereka yang laki-laki seperti anak laki-laki, saudara laki-laki dan bersifat kuat seperti dapat membawa senjata untuk mengalahkan musuh dalam setiap peperangan. ${ }^{7}$ Konsekuensinya, anak-anak baik laki- laki dan perempuan di larang mewarisi harta warisan harta peninggalan keluarganya. Ketentan semacam ini telah menjadi tradisi dan mengakar kuat dimasyarakat jahiliah. ${ }^{8}$

Untuk anak wanita yang tidak memiliki saudara laki-laki, maka ia berhak mewarisi, dengat syarat wanita tersebut harus menikah dengan laki-laki dari keluarganya, sehingga harta tidak keluar dari keluarga tersebut.

Setelah Islam datang, di masa-masa awalnya hukum kewarisan belum mengalami perubahan, dimana pembagian warisan hanya kekerabatan yang masih diakui sebagai dasar dalam hukum waris, sampai al-quran selesai di turunkan barulah hukum waris di kalangan masyarakat jahiliyah mengalami perubahan. Hal ini menunjukan bahwa tahap legislasi hukum diturunkan sesuai perkembangan sosial dan kondisi yang menyertainya. Setelah islam sempurna, dalam pembagian warisan tidak dikenal lagi pembedaan antar waris anak perempuan, dan anak laki-laki dalam memperoleh hak-haknya menerima warisan. ${ }^{9}$

Dasar hukum kewarisan Islam terdapat dalam al-Qur'an yang menegaskan secara defenitif ketentuan bagian ahli waris yang disebut dengan Furud al-Muqaddarah, 'Asabah dan orang-orang yang tidak termasuk ahli waris. Islam telah menjelaskan situasi dan kondisi seseorang yaitu kapan dia mendapatkan atau tidak dari harta warisan, kapan dia mendapatkan bagian pokok dan bagian sisa sekaligus, dan kapan seseorang terhalang mendapatkan bagian, atau dia tidak mendapatkan bagian sama sekali.

Di Indonesia, di antara orang-orang indonesia asli tidak terdapat satu sifat kekeluargaan saja, melaikan di berbagai daerah ada beberapa sifat kekeluargaan yang dapat di bilang menjadi tiga golongan, yaitu: ${ }^{10}$

dengan segala kecenderungan kepastian kebenarannya Mati taqdiri dapat dipahami sebagai kematian seseorang atas persangkaan yang di anggap mati dengan segala kecenderungan kepastian kebenarannya

${ }^{4}$ A. Sukris Sarmadis, Transendensi Keadilan Hukum Waris Islam Transformatif (Jakarta: Raja Grafindo Persada, 1997), h. 35-37

${ }^{5}$ Dewan Redaksi Ensiklopedi Islam, Ensiklopedi Islam, Jilid 3, (Jakarta: PT. Ikhtiar Baru Van Hoeve, 1993), h. 211

${ }^{6}$ Ibid.,

7 Ahamd Rofiq, Fiqh Mawaris (Jakarta: Raja Grafindo, 1995), h. 5. Lihat juga http://www.republika.co.id/berita/dunia-islam/hikmah/13/08/24/ms0foc-melacak-sejarah-hukum-waris, diakses tanggal, 20 Maret 2019.

${ }^{8}$ Ibid.,http://www.republika.co.id/berita/dunia-islam/hikmah/13/08/24/ms0foc-melacak-sejarah-hukumwaris, diakses tanggal, 20 Maret 2019.

${ }^{9}$ Ahamd Rofiq, Fiqh Mawaris., h.16.

${ }^{10}$ Sayuti Thib, Pembaharuan Hukum Islam di Indonesia (Jakarta: UI Press, 1981), h. 43. 
1. Kekeluagaan yang bersifat kebapakan (patrilineal)

Maksud dari kekeluargaan yang bersifat kebapakan, dimana seorang isteri karena perkawinannya ia terlepas dari hubungan kekeluargaan dengan orang tuanya dan sanak keluarganya. Sejak perkawinannya, isteri masuk atau berpindah kedalam lingkungan keluarga suaminya, begitu juga anak-anak keturunan dari perkawinan itu, kecuali dalam seorang anak perempuan yang sudah kawin maka ia masuk dalam lingkungan keluarga suaminya. ${ }^{11}$

Corak utama dalam perkawinan yang bersifat kebapakan ini adalah perkawinan dengan jujuran yaitu seorang calon isteri di beli oleh keluarga calon suaminya dari keluarga calon isteri tersebut dengan sejumlah uang, yang di tanah batak di namakan jujuran atau perunjuk atau antaran atau tuhor boli, dan di tanah gayo di namakan onjog. ${ }^{12}$ Kekeluargaan yang bersipat kebapakan ini di indonesia teerdapat di tanah gayo, alas, ambon, irian, dan bali. ${ }^{13}$

2. Kekeluargaan yang bersifat keibuan (matrilineal)

Kekeluargaan yang bersifat keibuan, di indonesia hanya terdapat di satu daerah yaitu di minangkabau. Di daerah ini, setelah satu perkawinan terjadi maka suami tinggal dirumah isteri atau keluarganya. Namun suami sendiri tidak termasuk dalam keluarga istri, dan anak-anak keturunannya dianggap kepunyaan ibunya saja, dan ayah pada hakekatnya tidak mempunyai kekuasaan terhadap anak-anaknya. Adapun yang berkuasa adalah saudara laki-laki ibu atau mama. ${ }^{14}$

3. Kekeluargaan yang bersifat kebapak-ibuan (parental / bilateral)

Kekeluargaan ini adalah yang paling umum yang terdapat di indonesia, yaitu di jawa, sumatra timur, riau, aceh, sumatra selatan, seluruh kalimantan, seluruh sulawesi, ternate, dan lombok. ${ }^{15}$ Sistem kekeluargaan seperti ini, pada hakekatnya tidak ada perbedaan kedudukan dalam keluarga masing-masing antara suami dan isteri. Suami sebagai akibat perkawinan menjadi anggota geluarga isteri, dan isteri juga menjadi anggota keluarga suami akibatnya,suami isteri masing-masing mempunyai dua keluarga. Begitulah seterusnya untuk anak-anak keturunannya tidak ada perbedaan antara laki-laki dan cucu perempuan. Sifat kekeluargaan demikian memiliki kaitan yang erat dengan masalah kewarisan. Maksudnya, sistem pewarisan yang berlaku di dalam masyarakat yang bersifat kebapak-ibuan memang agak berbeda dengan sifat kekeluargaan yang lain.

Adanya perbedaan dari ketiga macam sifat kekeluargaan tersebut akan menyebabkan adanya perbedaan dalam kewarisan pada tiga macam kekeluargaan itu. Dalam masyarakat patrilinial hanya laki-laki atau keturunan laki-laki saja yang berhak tampil sebagai ahli waris, sedangkan dalam bentuk matrilinial hanya wanitalah yang berhak tampil sebagai ahli waris. Bentuk kekeluargaan parental atau bilateral pada perinsipnya baik laki-laki dan perempuan dapat tampil sebagai ahli waris. ${ }^{16}$ Perbedaan pembagian warisan dengan berbedanya system kekeluargaan suatu daerah terasa semakin kompleks ketika bersentuhan dengan hukum waris Islam, ditambah dengan adanya terori receptio in complex, teori receptive Idan teori ireceptie a contrario mengakibatkan adanya tarik menarik antara hukum Islam, adat dan undang-undang. ${ }^{17}$

\footnotetext{
${ }^{11}$ Ibid.,

${ }^{12}$ Ibid., h. 44

${ }^{13}$ Ibid.

${ }^{14}$ M. Idris Ramulyo, Hukum Kewarisan Islam, Studi kasus Perbandingan Ajaran Syafi'I (Patrilinial), Hazairin (bilateral) dan Praktek di Peradilan Agama ( Jakarta: Grafikatama, 1987), h. 15

${ }^{15}$ Ibid.,

${ }^{16}$ M. Idris Ramulyo, Hukum Kewarisan Islam, Studi kasus Perbandingan Ajaran Syafi'I (Patrilinial), Hazairin (bilateral) dan Praktek di Peradilan Agama ( Jakarta: Grafikatama, 1987), h. 5

${ }^{17}$ Sayuti Thib, Pembaharuan Hukum Islam di Indonesia (Jakarta: UI Press, 1981), h. 45
} 
Tulisan ini dimaksudkan untukuntuk mengkaji dan menganalisis melalui hukum Islam terhadap kewarisan ayah dan ibu pada masyarakat Mandailing di Kabupaten Mandailing Natal.

\section{B. Persfektif Hukum Islam Tentang Bagian Waris Ayah Jika Suami Meninggal Lebih Dahulu}

\section{a. Sebab-sebab Mewarisi}

Warisan adalah istilah menurut bahasa Indonesia yang mengandung arti "harta peninggalan, pusaka, surat-surat wasiat". ${ }^{18}$

Menurut istilah bahasa Arab, disebut :

$$
\text { الإرث و الورث و الرثة (مصادر) ما يخلفه الميت لورثته19 . }
$$

Artinya:"Suatu yang ditinggalkan oleh orang yang meninggal untuk ahli warisnya".

Menurut istilah syara' para fukaha menyebutkan dengan :

$$
\text { حق الجزئة ويثبت لمستحقه بعد موت من كان له ذلك الحق بسبب القر ابة و النكاح و الو لاء20. . }
$$

Artinya: "Suatu hak yang bisa dibagi dan diberikan orang yang berhak kepadanya setelah wafatnya orang yang punya hak tersebut dengan sebab kerabat, perkawinan dan memerdekakan".

Dikalangan faradhiyun dikenal juga istilah tirkah untuk warisan. Adapun yang dimaksud dengan tirkah itu adalah :

$$
\text { التركة هي مايتركه الميت من الأموال .21 }
$$

Artinya : "Suatu yang ditinggalkan oleh mayit berupa harta mutlak".

Kalangan Mazhab Syafi'imenyebutkan :

$$
\text { ماليةّ22 عند المالكيه و الثافعيه ولحنابلتتشمل جميع ما يتركه الميت من اموال وحقوق سواء كانتالحقوق ماليةام غير }
$$

Artinya: Dan tirkah dikalangan Malikiyah, Syafi'iyah dan Hanabilah, yaitu meliputi sekalian yang ditinggalkan mayit dari harta atau bentuk hak-hak baik berupa hak kebendaan atau selain hak kebendaan tersebut".

Sedangkan pengertian menurut istilah dikalangan Malikiyah, Syafi'iyah dan Hanabilah mengatakan bahwa tirkah adalah sekalian yang ditinggalkan mayit baik berbentuk harta maupun hak-hak yang lain selain harta.Selanjutnya dari uraian-uraian diatas dapat diambil suatu pengertian bahwa harta warisan adalah harta yang telah ditinggalkan oleh si mayit yang akan dibagikan kepada semua ahli waris yang berhak menerimanya setelah kematiannya, dengan syarat setelah dikeluarkan biaya keperluan si mayit dengan segala yang ada hubungan dengan harta tersebut dengan orang lain, seperti wasiat ataupun hutang-piutang.

${ }^{18}$ WJS. Purwadarta, Kamus Besar Bahasa Indonesia, (Jakarta: PN. Balai Pustaka, 1983), h. 148.

${ }^{19}$ Louis Ma'lup, al-Munjid Fi al-Lughah wa al-'Alam,(Bairut: al- Syarghiyah, 1973), h. 89.

${ }^{20}$ Abdul Rahman Yusuf Jalal, al-Khulashah al- Wafiyah fi al-Mawaris al-Islamiyah, (Kairo: Dar alTa'lifi, 1969), h. 1 .

${ }^{21}$ Sayyid Sabiq, Fiqh al- Sunnah, (Bairut: Dar al-Fikr, 1981, Jilid III), h. 425.

${ }^{22}$ Ibid,. 
Allah swt berfirman dalam surat An-Nisaa ayat 12 sebagai berikut :

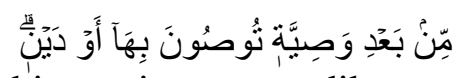

Artinya: “... Sesudah dipenuhi wasiat yang dibuat olehnya atau sesudah dibayar hutangnya...". 23

Dalam kitab al-umm, Imam Syafi'i tidak ada menjelaskan pengertian warisan secara defenitif, karena itu pengertian warisan menurut Imam Syafi'i memandang dari perkataan umum dari pembahasannya.

$$
\text { قال الثافعى فرض الله ميرث الو الدين وإخوة و الزوجة الزوجة }
$$

Artinya: "Berkata as-Syafi'i semoga Allah Ta'ala merahmatinya : Allah Ta'ala memfardhukan warisan kepada kedua orang tua, saudara-saudara, istri dan suami".

Penjelasan diatas dapat dipahami bahwa secara defenitif warisan hanya diberikan kepada orang yang berhak menerimanya seperti kedua orang tua, anak saudara-saudara, istri dan suami, berdasarkan ketentuan masing-masing sebagaimana yang telah di atur dalam hukum waris itu sendiri.

Selanjutnya Imam Syafi'i menyebutkan :

$$
\text { فولت سنة رسول الله عليه وسلم اقاويل اكثر اهل العلم على ان معنى الأيةان اهل الموارث انما ورثو اذا كانوفي حال }
$$

Artinya : "Sunnah Rasulullah saw menyebutkan kemudian juga perkataan kebanyakan ahli ilmu bahwa makna ayat al-qur'an tentang warisan adalah sesungguhnya mereka menerima warisan apabila ada dalam satu keadaan tertentu tidak dalam keadaan yang lain".

Makna dari pernyataan di atas dapat difahami bahwa warisan adalah pemberian disatu pihak dan penerima di pihak yang lain karena ada ketentuan yang telah di atur menurut syara' untuk boleh atau tidak menerima harta warisan tersebut.Dengan demikian dari penjelasan-penjelasan diatas dapat diambil satu pengertian bahwa warisan adalah suatu kewajiban yang telah ditetapkan Allah swt kepada seseorang dalam keadaan tertentu pula dan tidak dalam keadaan lainnya, artinya warisan telah ada ketetapannya dalam hukum Islam, siapa dan berapa bagiannya sesuai dengan keadaan orang yang bersangkutan dan masalahnya.

Ada tiga sebab sehingga orang tersebut memiliki hak untuk mewarisi harta, yaitu :
a. Perkawinan
b. Kekerabatan
c. Wala' 26

Maksud perkawinan adalah perkawinan yang sah menurut syariat Islam, dengan adanya suatu ikatan perkawinan merupakan ikatan yang dapat mempertemukan seorang laki-laki dengan seorang wanita dengan suatu rumah tangga, selama perkawinan itu masih utuh dipandang sebagai salah satu sebab mewarisi, baik setelah keduanya bersetubuh atau belum. Sebab jika telah terjadi akad nikah maka terjadilah waris mewarisi diantara mereka, apabila salah seorang meninggal dunia.

Fatchur Rahman menyebutkan bahwa, suatu perkawinan masih dianggap utuh apabila perkawinan itu telah diputuskan dengan thalak raja'i, tetapi masih dalam iddah raja'i, perkawinan itu masih dianggap utuh sebab suami masih mempunyai hak penuh

\footnotetext{
${ }^{23}$ Departemen Agaman RI, al-Qur'an ddan Terjemahannya, (Semarang: Toha Putra, 1989), h. 117.

${ }^{24}$ Muhammad bin Idris al- Syafi'I, al-Umm, (Mesir: Dar al-Syu'bi, Juz IV, t,t). h. 2.

${ }^{25} \mathrm{Ibid}$,

${ }^{26}$ Fatchur Rahman, Ilmu Waris, (Bandung : PT al- Ma’arif, 1981), h. 113.
} 
untuk merujuk kembali bekas istrinya yang masih menjalankan iddah, tanpa memerlukan kerelaan hati istri. ${ }^{27}$

\section{b. Ahli Waris dan Bagian Masing-Masing}

Secara garis besar ahli waris dalam Islam di bagi menjadi 2 golongan yaitu menurut sebab mendapatkannya, dan menurut bagiannya.

Menurut Sebab Mendapatkannya, ahli waris dari segi sebab mendapatkannya ada tiga golongan yaitu Ahli waris Nasabiyah, Ahli waris Sababiyah dan wala'.

1) Ahli waris Nasabiyah: mendapatkan waris dengan jalan nasab atau kekerabatan. Ahli waris nasabiyah ini di bagi lagi dalam tiga golongan, yaitu:

- Furu' (anak turun [cabang] dari si mati) yaitu Anak laki-laki, Anak perempuan, Cucu laki-laki pancar laki-laki, Cucu perempuan pancar laki-laki, Sampai ke bawah betapapun jauhnya.

- Ushul (leluhur [pokok] yang menyebabkan adanya si mati) yaitu Ayah, Ibu, Kakek (shohih), Nenek (shohihah), Sampai keatas betapun tingginya.

- Hawasyi (keluarga yang di hubungkan dengan si mati dengan garis menyamping) yaitu Saudara laki-laki, Saudara perempuan, Saudara seayah, Saudari seayah, Saudara-saudari tunggal ibu, Paman, Dan anak turunnya tanpa membedakan laki-laki atau perempuan. ${ }^{28}$

2) Ahli waris sababiyah: mendapatkan warisan dikarenakan suatu sebab, yaitu pekawinan yang sah. Syarat-syarat suami / istri bisa mewaris:Pertama, perkawinan yang dilakukan sah menurut syari'at islam Kedua, ikatan perkawinan antara suami-istri itu masih utuh/dianggap masih utuh. Perkawinan dianggap masih utuh ialah apabila perkawinan itu telah diputuskan dengan talak raj'iy, tetapi masa iddah raj'iy bagi seorang istri belum selesai. Perkawinan tersebut dianggap masih utuh , karen adisaat iddah masih berjalan suami mempunyai hak penuh untuk merujuk kembali bekas istrinya yang masih menjalankan iddah. ${ }^{29}$

3) Wala':dalam syari'at mempunyai pengertian: pertama Kekerebatan menurut hukum yang timbul karena membebaskan atau memberi hak emansipasi terhadap budak, kedua Kekerabatan menurut hukum yang timbul karena adanya perjanjian tolong menolong dan sumpah setia antara seseorang dengan seseorang yang lain.Wala' dalam arti yang pertama disebut dengan wala'ul- 'ataqah atau 'ushubah sababiyah, yakni 'ushubah yang bukan disebabkan karena adanya pertalian nasab, tetapi disebabkan karena adanya sebab telah membebaskan budak. Wala' juga dapat di masukkan kedalam ahli waris sababiyah. ${ }^{30}$

Seperti halnya ahli waris menurut sebab mendapatkannya, ahli waris dari segi bagiannya pun di bagi menjadi tiga golongan, yaitu: Dzawi al-Furudl, Ashobah, Dzawi alArham.

${ }^{27}$ Ibid., h. 119.

${ }^{28}$ Fatchur Rahman, Ilmu waris, (Bandung: PT. Al-Ma;arif, 2007), h. 109

${ }^{29}$ Ibid, h. 115

${ }^{30}$ Apabila seorang pemilik budak telah membebaskan budaknya dengan mencabut hak kewaliannya dan hak mengurusi harta bendanya, maka ia telah merubah status seeorang yang semula tidak dapat bertindak, menjadi dapat memiliki, mengurusi dan mengadakan transaksi-transaksi terhadap harta bendanya sendiri, dan dapat melakukan tindakan hukum yang lain. Sebagai kenikmatan yang telah diberikan terhadap budaknya dan sebagai imbalan atas melaksanakan anjuran syari'at untuk membebaskan budak, syariat memberikan hak wala' padanya. Oleh karena itu wala' oleh Rasulullah SAW dianggap sebagai kerabat berdasarkan nasab. Sedang walak dalam arti kedua disebut dengan walaul-muwalah, misalnya seorang berjanji sebagai berikut: "hai saudara, engkau adalah tuanku yang dapat mewarisi aku jika aku telah mati dan dapat mengambil diyah (tebusan) untukku jika aku dilukai seseorang". Namun wala' menjadi sebab mempusakai ini sudah di nasakh dalam KUHW Mesir (jumhur ulama')., Ibid, h. 122- 123 


\section{1) Dzawi al-Furudl dan Furud al-muqaddarah-nya}

Dzawi al-furudl adalah ahli waris yang sudah diterntukan di dalam Al-Qur'an, yaitu ahli waris langsung yang mesti selalu mendapat bagian tetap tertentu yang tidak berubah-ubah. ${ }^{31}$ Mereka semua ada dua belas orang, empat orang lelaki dan delapan orang wanita. Ashhabul furudl dari lelaki adalah, suami, ayah, kakek sejati, dan saudara dari ibu. Ashhabul furudl dari wanita ialah, isrti, ibu, nenek sejati, anak perempuan sekandung, cucu perempuan dari anak laki-laki, saudara perempuan sekandung, saudara perempuan seayah, dan saudara perempuan seibu. ${ }^{32}$ Para ahli waris diatas (dzawi al-furudl) mempunyai bagian-bagian yang sudah di tentukan dalam nash atau dengan ijma' (furud al-muqaddarah). Syari'at Islam menentukan furud al-muqaddarah tersebut ada 6 macam, yaitu: Dua pertiga (2/3), Sepertiga (1/3), Seperenam (1/6), Seperdua/separo (1/2), Seperempat (1/4), Seperdelapan $(1 / 8){ }^{33}$

Diasamping furud al-muqaddarah yang 6 tersebut, masih terdapat satu macam furud al-muqddarah hasil ijtihad para jumhur fuqaha, yaitu sepertiga sisa harta peninggalan. Adapun skema pembagiannya adalah:

a) Ahli waris yang mendapatkan bagian dua pertiga (2/3) ada 4 orang:

- 2 orang anak perempuan atau lebih, dengan ketentuan tidak bersama dengan mu'ashibnya (yang menjadikannya 'ashobah)

- 2 orang cucu perempuan pancar laki-laki, dengan ketentuan bila mereka tidak bersama-sama anak perempuan kandung atau mu'ashibnya.

- 2 orang saudari sekandung atau lebih, dengan ketentuan mereka tidak bersama-sama dengan mu'ashibnya.

- 2 orang saudari seayah atau lebih, dengan ketentuan bila simati tidak mempunyai anak perempuan kandung, atau cucu perempuan pancar laki-laki, atau saudari kandung.

b) Ahli waris yang mendapatkan bagian sepertiga (1/3)

- Ibu, dengan ketentuan ia tidak bersama-sama dengan far'u waris, laki-laki maupu permpuan atau bila ia tidak bersama-sama dengan 2 orang saudarasaudari sekandung atau seayah atau seibi saja.

- Anak-anak ibi (saudara seibu bagi si mati) laki-laki maupun perempuan 2 orang atau lebih, dengan ketentuan bila mereka tidak bersama-sama far'u waris laki-laki maupun perempuan atau tidak bersama-sama denagn ashlu waris laki-laki (seperti ayah, kakek shahihah).

c) Ahli waris yang mendapatkan bagian sepererenam (1/6) ada 7 orang, yaitu:

- Ayah, dengan ketentuan bila ia bersama-sama dengan far'u waris laki-laki (yaitu anak laki-laki, cucu laki-laki pancar laki-laki betapa jauh menurunnya)

- Ibu, dengan ketentuan bila ia mewarisi bersama-sama dengan far'u waris secara mutlak atau bersama-sama dengan dua orang atau lebih saudara saudari secara mutlak.

- Kakek shahih, bila ia me warisi bersama-sama far'u waris laki-laki.

- Nenek shahihah, bila ia tidak bersama-sama dengan ibu.

- Saudara seibu, laki-laki maupun perempuan, bila ia mewarisi bersama-sama dengan far'u waris laki-laki maupun perempuan atau mewarisi bersamabersama dengan ashlu waris laki-laki.

\footnotetext{
${ }^{31}$ Eman Suparman Hukum waris Indonesia ( Bandung: PT Refika Aditama, 2007),h. 17

${ }^{32}$ Hasbi Ash Shiddieqy, Fiqh Mawaris (Semarang: Rineka Cipta, 2011), h. 6

${ }^{33}$ Fathurrahman, Fiqh.., h. 128
} 
- Cucu perempuan pancar laki-laki, bila ia mewarisibersama-sama dengan seorang anak perempuan kandung.

- Seorang saudari seayah atau lebih, bila ia bersama-sama dengan saudari kandung.

d) Para ahli wris yang mendapatkan bagian seperdua (1/2), ada 5 orang, yaitu:

- Seorang anak perempuan, dngan ketentuan bila ia tidak bersama dengan anak laki-laki yang menjadi mu'ashibnya.

- Seorang cucu perempuan pancar laki-laki, dengan ketentuan bila ia tidak bersama-sama dengan anak perempuan atau orang laki-laki yang menjadi mu'ashibnya.

- Suami, bila ia tidak bersama-sama far'u waris.

- Seorang saudari kandung, bila ia tidak mewarisi bersama-sama dengan mu'ashibnya.

- Seorang saudari seayah, bila ia tidak bersama-sama dengan anak perempuan kandung, atau cucu perempuan pancar laki-laki, atau saudari kandung.

e) Para ahli waris yang mendapatkan bagian seperempat (1/4), ada 2 orang, yaitu:

- Suami, dalam keadaan bila ia mewarisi bersama-sama dengan far'u waris bagi si istri, baik yang lahir dari perkawinannya dengan suami tersebut, maupun yang lahir dari perkawinannya dengan suami yang terdahulu.

- Istri, dengan ketentuan bila tidak mewarisi bersama-sama dengan far'u waris, baik yang lahir dari perkawinannya iti sendiri, ataupn dengan istri yang terdahulu.

f) Ahli waris yang mendapatkan bagian seperdelapan (1/8), hanya 1 orang, yaitu istri dalam keadaan bila ia mewarisi bersama-sama dengan far'u waris bagi suami, baik yang lahir dari perkawinannya dengan istri tersebur, maupun istri terdahulu.

Adapun bagian sepertiga sisa (hasil ijtihad fuqaha) dimiliki oleh ibu, dalam keadaan ia mewarisi bersama-sama dengan ayah dan salah seorang dari suami-istri bagi si mati. $^{34}$

\section{2) 'Ashabah dan bagiannya}

Lafadz ashobah menurut bahasa berarti kerebat seseorang dari jurusan ayah atau anak lelaki dan kaum kerabat dari pihak bapak. ${ }^{35}$ Sedangkan menurut ajaran kewarisan patrilineal syafi'i ialah: golongan ahli waris yang mendapatkan bagian terbuka atau sisa. Ahli waris ahobah ini menurut pembagian hazarain dalam bukunya "Hukum Kewarisan Bilateral Menurut Al-Qur'an" dinamakan ahli waris bukan dzul faraidl, yang kemudian beliau membagi ahli waris ashobah menjadi 3 golongan, yaitu: ashobah binafsihi, ashabah bilghoiri, ashobah ma'alghoir. ${ }^{36}$

a) ashobah binafsi: ialah kerabat laki-laki yang bipertalikan dengan si mati tanpa diselingi oleh orang perempuan. Golongan ashobah binafsi ini berhak mendapatkan semua harta atau semua sisa, yang termasuk di dalamnya yaitu: Anak laki-laki, Cucu laki-laki dari anak laki-laki dan terus kebawah asal saja pertaliannya masih terus laki-laki, Ayah, Kakek dari pihak ayah dan terus ke atas asal saja pertaliannya belum putus dari pihak ayah, Saudara laki-laki sekandung, Saudara laki-laki seayah, Anak saudara laki-laki sekandung, Anak saudara laki-laki, Paman yang sekandung dengan ayah, Paman yang seayah dengan ayah, Anak laki-laki

\footnotetext{
${ }^{34}$ Ibid, h. 130

${ }^{35}$ Menurut istilah Fradhiyun ialah: ahli waris yang tudak mendapat bagian yang sudah dipastikan besar kecilnya yang telah disepakati oleh fuqoha maupun yang belum disepakati oleh mereka.Eman Suparman, Hukum Waris, h. 18

${ }^{36}$ Ibid, h. 19
} 
paman yang sekandung dengan ayah, Anak laki-laki paman yang seayah dengan ayah. $^{37}$

Adapun garis keturuna (jihat) ashobah binnafsi adalah:

1) Jihat bunuwwah: keturunan langsung dari yang meninggal, seperti anak lakilaki, cucu laki-laki pancar laki-laki walaupun betapa rendah derajadnya.

2) Jihat ubuwwah: asal (orang tua) dari yang meninggal, ayah dan nenek sejati walaupun sudah berapa tinggainya.

3) Jihat ukhuwahpersaudaraan dengan yang meninggal, termasuk saudara lakilaki seibu sepabak (saudara kandung) atau sebapak, dan anak lelaki mereka walaupun berapa jauhnya.

4) Jihat umummah: bersepupu (misan) dari yang meninggal, paman dari yang meninggal, paman dari kakek sejati, berapun tingginya, dan juga anak lelaki dari anak lelaki mereka berapapun jauhnya. ${ }^{38}$

b) ashabah bilghoir

ashabah bilghoir adalah seorang wanita yang menjadi asahabah karena ditarik oleh seorang laki-laki. Pengertian yang lain yang dikemukakan Drs.Fatchur Rahman dalam bukunya Ilmu Waris ialah, setiap perempuan yang memerlukan orang lain untuk menjadikan ashabah dan untuk bersama-sama menerima ushubah. Ashabah bilghoir itu ada 4 orang wanita, keempatnya dari golongan asahabul furudl yang mendapatkan $1 / 2$, kalau dia hanya seorang, dan mendapatkan 2/3 kalau lebih dari seorang, mereka adalah: Anak perempuan kandung, Cucu perempuan pancar laki-laki, Saudari sekandung, Saudari tunggal ayah. ${ }^{39}$

c) ashabah ma'alghair

Ashabah ma'alghair Ialah, saudara perempuan yang mewaris bersama keturunan dari pewaris, mereka adalah: Saudara perempuan sekandung, Saudara perempuan seayah. Kedua orang tersebut dapat menjadi ashabah ma'alghair dengan syarat-syarat:

- Berdampingan dengan seorang atau beberapa orang anak perempuan atau cucu perempuan pancar laki-laki sampai berapapun jauh menurunnya.

- Tidak berdampingan dengan saudaranya yang menjadi mu'ashibnya (saudara lakilaki). ${ }^{40}$

\section{3) Dzawi al-arham}

Pengertian dzawi al-arham ialah orang yang mempunyai hubungan darah dengan pewaris melalui pihak wanita saja. Sedangkan ulama'-ulama' faraidh menyatakan bahwa dzawi al-arham adalah para ahli waris selain ashab al-wurudl dan ashabah. Pembagian dzawi al-arham:

a. Orang yang berhubungan dengan orang yang meninggal, sedang ia bukan dzawi al-furudh atau ashabah.

b. Orang yang berhubungan dengan yang meninggal, karena yang meninggal itu dinishbatkan kepada mereka lantaran mereka adalah ayah-ayah dari yang meninggal.

\footnotetext{
${ }^{37}$ Jika ashobah binafsi ini mewarisi bersama-sama dengan ahli waris ashhabul furudl, maka mereka menerima sisa dari ashabul furudl selama bagian-bagian mereka yang terkahir tidak sampai menghabiskan seluruh harta peninggalan. Dengan demikian bisa terjadi para ahli waris ashobah, tidak memperoleh bagian sedikitpun, bila ternyata harta peninggalan sudah terwariskan habis oleh ashhabul furudl. Jika ashobah itu hanya seorang diri saja dan masih ada sisa harta peninggalan, atau para ahli waris yang bakal mewarisi tidak ada golongan ashhabul furudlnya sama sekali, maka sisa atau seluruh harta peninggalan diwarisinya sendiri, tetapi jika ashobah lebih dari satu maka diadakan seleksi menurut garis keturunannya (jihat). Ibid, h. 21

${ }^{38}$ Hasbi Ash-Siddiqy, Fikih Waris, h. 164

${ }^{39}$ Fathurrahman, Hukum Waris, h.347

${ }^{40}$ Ibid, h. 348
} 
c. Orang yang berhubungan kepada ayah dan ibu yang meninggal

d. Orang-orang yang berhubungan kepada kakek-kakek yang meninggal. ${ }^{41}$

Para fuqaha' golongan shahabt, tabi'in dan imam-imam madzhab yang menyusul kemudian memperselisihkan apakah dzawi al-arham itu dapat mempusakai harta peninggalan atau tidak. Dalam hal ini terdapat dua pendapat yang saling berlawanan. ${ }^{42}$

\section{c. Hak Waris Ayah dan Ibu}

Sistem waris merupakan salah satu sebab atau alasan adanya pemindahan kepemilikan, yaitu berpindahnya harta benda dan hak-hak material dari pihak yang mewarisakan, setelah yang bersangkutan wafat kepada penerima warisan dengan jalan pergantian yang didasarkan pada hukum syara'. Syara' telah menentukan orang-orang yang berhak mendapat warisan (ashab al-Furud) ${ }^{43}$ dan besar bagianya masing-masing (Furud al-muqaddarah) ${ }^{44}$ dengan rinci. Firman Allah: "ini adalah ketetapan dari Allah. Sesungguhnya Allah Maha mengetahui lagi Maha Bijaksana”. (Q.S. an-Nisa':11) dan sambungannya "Allah menetapkan yang demikian itu sebagai) syari'at yang benar-benar dari Allah, dan Allah Maha mengetahui lagi Maha Penyantun” (Q.S an-Nisa': 12).

Penggalan ke dua ayat ini dengan tegas memberi isyarat bahwa Allah yang berkompeten dan paling berhak untuk mengatur pembagian harta warisan. Hal ini tidak diserahkan kepada manusia, siapa pun orangnya, cara ataupun aturan pembagiannya, karena bagaimanapun bentuk usaha manusia untuk mewujudkan keadilan tidaklah akan mampu melaksanakannya secara sempurna. Bahkan tidak akan dapat merealisasikan pembagian yang adil seperti yang telah ditetapkan dalam ayat-ayat Allah Swt.

Besar bagian ayah da ibu dijelaskan dalam Al-qur'an surat Annisa: 11, yaitu:

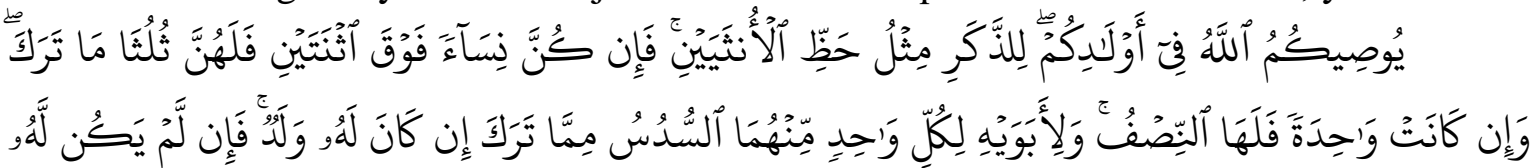

${ }^{41}$ Hasbi ash-Siddiqy, Fiqh Mawaris, h. 236

${ }^{42}$ Pertama, pendapat yang mengatakan bahwa dzawi al-arham itu tidak dapat mewarisi sama sekali. Jadi andaikan ada seorang yang meninggal duniadengan tidak meninggalkan ahli waris dzawi al-furudl atau ashabah, harta warisnya diserahkan ke baitul mal, meakipun ia meninggalkan ali waris dzawi alarhamUlama' ulama' yang berpendapat demikian dari golongan shahabat adalah Zaid bin Tsabit dan Ibnu Abbas r.am,,dari golongan tabi'in adalah Sa'id Ibnu al-Musayyab, Sa'ad bin Jubair, dab dari golongan fuqaha yang terkenal ialah, Sufyan as-Tsauri, Imam Malik, Imam as-Syafi'iy, al-Auza'i, dan Ibnu Hazm. Kedua, pendapat yang mengatakan bahwa dzawi al-arham dapat mewarisi harta peninggalan, bila seorang yang meninggal dunia tidak meninggalkan ahli waris dzawi al-furudh yang dapat menerima radd atau ahli waris ashabah. Diantara ulama' yang berpendapat demikian dari golongan shahbat adalah 4 khulafa al-rasyidin, Ibnu Mas'ud, Mi'adz bin Jabbal r.um.. dari golongan tabi'an antara lain ialah Syuraih Alqodli, Ibnu Sirrin Atha' dan Mujahid, dari golongan imam madzhab dan mujtahid ialah, Imam Abu Hanifah, Imam Ahmad bin Hambal, Abu yusuf, dan fuqaha'-fuqaha' terkemudian dari pengikut setia mazhab Syafi'iyah, dan Malikiyah Fathurrahman, Ilmu Waris, h. 353- 354

${ }^{43}$ Secara bebas, arti lugowi zawi al-furud adalah orang-orang yang mempunyai saham (bagian) pasti. Secara istilahi zawi al-furud adalah ahli waris yang sahamnya telah ditentukan secara terperinci (seperdua, sepertiga, seperempat, seperenamatau seperdelapan dari warisan. Ahmad Rafiq, MA. Fiqh Mawaris, (Jakarta: Raja Grafindo Persada, 1995), Cet. 2, h. 54.

${ }^{44}$ Furudlu menurut istilah fiqih mawarits, ialah bagian yang sudah ditentukan jumlahnya untuk warits pada harta peninggalan, baik dengan nash maupun dengan ijma'. Kata al-furud adalah bentuk jamak dari kata fard artinya bagian (ketentuan). Al-Muqaddarah artinya ditentukan. Jadi al-furud al-muqaddarah adalah bagian-bagian yang telah ditentukan oleh syara' bagi ahli waris tertentu dalam pembagian harta peninggalan. Bagian itulah yang akan diterima ahli waris menurut jauh dekatnya hubungan kekerabatan. T.M. Hasbi AshShidieqy. Fiqih Mawaris (Hukum-hukum Warisan dalam Syari'at Islam),(Jakarta: Bulan Bintang, 1967), h. 74 


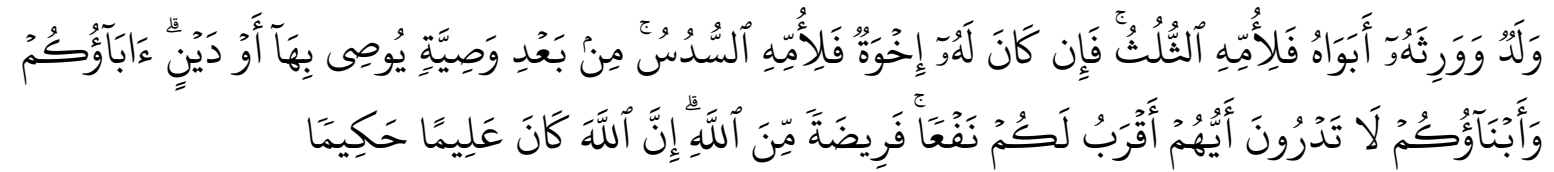

11. Allah mensyari'atkan bagimu tentang (pembagian pusaka untuk) anak-anakmu. Yaitu: bahagian seorang anak lelaki sama dengan bagahian dua orang anak perempuan; dan jika anak itu semuanya perempuan lebih dari dua, maka bagi mereka dua pertiga dari harta yang ditinggalkan; jika anak perempuan itu seorang saja, maka ia memperoleh separo harta. Dan untuk dua orang ibu-bapa, bagi masing-masingnya seperenam dari harta yang ditinggalkan, jika yang meninggal itu mempunyai anak; jika orang yang meninggal tidak mempunyai anak dan ia diwarisi oleh ibu-bapanya (saja), maka ibunya mendapat sepertiga; jika yang meninggal itu mempunyai beberapa saudara, maka ibunya mendapat seperenam. (Pembagian-pembagian tersebut di atas) sesudah dipenuhi wasiat yang ia buat atau (dan) sesudah dibayar hutangnya. (Tentang) orang tuamu dan anak-anakmu, kamu tidak mengetahui siapa di antara mereka yang lebih dekat (banyak) manfaatnya bagimu. Ini adalah ketetapan dari Allah. Sesungguhnya Allah Maha Mengetahui lagi Maha Bijaksana.

Dari ayat di atas dapat dipahami bahwa:

1. Ayah dan ibu masing-masing mendapatkan seperenam bagian apabila yang meninggal mempunyai keturunan.

2. Apabila pewaris tidak mempunyai keturunan, maka ibunya mendapat bagian sepertiga dari harta yang ditinggalkan. Sedangkan sisanya, yakni dua per tiga menjadi bagian ayah. Hal ini dapat dipahami dari redaksi ayat yang hanya menyebutkan bagian ibu, yaitu sepertiga, sedangkan bagian ayah tidak disebutkan. Jadi, pengertiannya, sisanya merupakan bagian ayah.

3. Jika selain kedua orang tua, pewaris mempunyai saudara (dua orang atau lebih), maka ibunya mendapat seperenam bagian. Sedangkan ayah mendapatkan lima per enamnya. Adapun saudara-saudara itu tidaklah mendapat bagian harta waris dikarenakan adanya bapak, yang dalam aturan hukum waris dalam Islam dinyatakan sebagai hajib (penghalang). Jika misalnya muncul pertanyaan apa hikmah dari penghalangan saudara pewaris terhadap ibu mereka --artinya bila tanpa adanya saudara (dua orang atau lebih) ibu mendapat sepertiga bagian, sedangkan jika ada saudara kandung pewaris ibu hanya mendapatkan seperenam bagian? Jawabannya, hikmah adanya hajib tersebut dikarenakan ayahlah yang menjadi wali dalam pernikahan mereka, dan wajib memberi nafkah mereka. Sedangkan ibu tidaklah demikian. Jadi, kebutuhannya terhadap harta lebih besar dan lebih banyak dibandingkan ibu, yang memang tidak memiliki kewajiban untuk membiayai kehidupan mereka.

Firman Allah Swt yang artinya: "orang tuamu dan anak-anakmu, kamu tidak mengetahui siapa di antara mereka yang lebih dekat (banyak) manfaatnya bagimu." Manusia tidak akan tahu manakah di antara orang tua dan anak yang lebih dekat atau lebih besar kemanfaatannya terhadap seseorang, tetapi Allah, Maha Suci Dzat-Nya, Maha Bijaksana lagi Maha Mengetahui. Pembagian yang ditentukan-Nya pasti adil. Bila demikian, siapakah yang dapat membuat aturan dan undang-undang yang lebih baik, lebih adil, dan lebih relevan bagi umat manusia dan kemanusiaan selain Allah Swt.

\section{Praktek Pembagian Warisan Pada MasyarakatMandailing di Kabupaten Mandailing Natal}

1. Bagian ayah dan ibu dalam system kewarisan pada masyarakat Mandailing di Kabupaten Mandailing Natal

Hukum kekeluargaan Indonesia, terdapat beberapa sifat kekeluargaan yang dapat di bilang menjadi tiga golongan, yaitu: Kekeluagaan yang bersifat kebapakan (patrilineal), 
Kekeluargaan yang bersifat keibuan (matrilineal) dan Kekeluargaan yang bersifat kebapak-ibuan (parental / bilateral).

Adanya perbedaan dari ketiga macam sifat kekeluargaan tersebut akan menyebabkan adanya perbedaan dalam sifat kewarisan pada tiga macam kekeluargaan itu. Dalammasyarakat patrilinial hanya laki-laki atau keturunan laki-laki saja yang berhak tampil sebagai ahli waris, sedangkan dalam bentuk matrilinial hanya wanitalah yang berhak tampil sebagai ahli waris. Bentuk kekeluargaan parental atau bilateral pada perinsipnya baik laki-laki dan perempuan dapat tampil sebagai ahli waris. ${ }^{45}$

Perbedaan pembagian warisan dengan berbedanya sistem kekeluargaan suatu daerah terasa semakin kompleks ketika bersentuhan dengan hukum waris Islam, ditambah dengan adanya terori recetio in complex, teori receptive Idan teori ireceptie a contrario mengakibatkan adanya tarik menarik antara hokum Islam, adat dan undangundang. ${ }^{46}$ Dalam hal warisan, masyarakat Mandailing di Kabaupaten Mandailing Natalmerupakan masyarakat yang menganut sistem kekeluargaan parental atau bilateral, karena dalam kebiasaan masyarakat Mandailing di Kabaupaten Mandailing Natalbaik lakilaki maupun perempuan dapat tampil sebagai ahli waris. Meskipun demikian penulis melihat bahwa dalam prakter pembagian harta warisan pada masyarakat Mandailing di Kabaupaten Mandailing Natalterdapat kejanggalan yaitu pada hak waris Ayah dan Ibu.

Sistem kewarisan masyarakat Mandailing di Kabaupaten Mandailing Natal yang paling berhak mendapat warisan adalah anak dan istri si mayit. Adapaun ahli waris yang lain tidak akan mendapat warisan jika si mayit meninggalkan istri dan anak. ${ }^{47}$ Dalam prakteknya, apabila ahli waris yang ditinggalkan terdiri dari isti dan anak laki-laki serta anak perempuan maka ayah atau ibu tidak akan mendapat warisan, artinya dengan adanya anak laki-laki atau anak perempuan ahli waris yang lain jadi terhalang tidak terkecuali ayah dan ibu. ${ }^{48}$

Pada pembahasan sebelumnya dapat dipahami bahwa ahli waris selain anak (baik laki-laki maupun perempuan) hanya akan mendapat warisan jika si mayit tidak meninggalkan anak. Dengan kata lain ayah dan ibu terhalang mendapat warisan jika tidak anak laki-laki atau anak perempuan, padahal dalam kewarisan Islam Ayah dan Ibu merupakan orang yang tidak bisa dihijab oleh siapapun.

Hal serupa juga disampaikan oleh Abdus Samad, beliau mengatakan bahwa dalam tradisi masyarakat Panyabungan Utara jika anak masih ada maka ayah dan ibu tidak mendapat warisan, akan tetapi jika si mayit meninggalkan ahli waris selain anak maka ayah/ibu mendapat warisan. ${ }^{49}$

Senada dengan Abduss Samad, M. Taufiq juga mengatakan bahwa pembagian warisan sudah begitu sejak dulu, sudah menjadi kebiasaan pada masyarakat jika si seseorang meninggal hartanya diwarisi anak-anaknya meskipun si mayit masih mempunyai ayah atau ibu. Beliau juga menambahkan bahwa karena pembagian warisan

${ }^{45}$ M. Idris Ramulyo, Hukum Kewarisan Islam, Studi kasus Perbandingan Ajaran Syafi'I (Patrilinial), Hazairin (bilateral) dan Praktek di Peradilan Agama ( Jakarta: Grafikatama, 1987), h. 5

${ }^{46}$ Sayuti Thalib, Pembaharuan Hukum Islam di Indonesia (Jakarta: UI Press, 1981), h. 45

${ }^{47}$ Mawardi Lubis, tokoh masyarakat, wawancara pribadi, Panyabungan Utara, Kabuapaten Mandailing Natal. 2019

${ }^{48}$ Ikmal shadiqqin, tokoh Agama Panyabungan Utara, wawancara pribadi, Panyabungan Utara Kabuapaten Mandailing Natal. 2019

49 Abdus Samad, BKM Masjid Nurul Muttaqin Panyabungan Utara, wawancara Pribadi, Panyabungan Utara Kabuapaten Mandailing Natal. 2019 
yang ada sudah sejak dulu maka seorang ayah atau ibu tidak pernah mempersoalkan ketika anknya meninggal dan warisannya hanya diwarisi oleh anak dan istrinya saja. ${ }^{50}$

Selanjutnya, M. Ibrahim mengatakan: Pada dasarnya ayah atau ibu berhak menerima warisan dari harta peninggalan anaknya sebagaimana hukum waris dalam alqur'an dan hadis rasul. Namun karena sudah menjadi kebiasaan masyarakat bahwa ayah atau ibu tidak mendapat bagian jika si mayit mempunyai anak maka hal ini juga sudah tidak menjadi hal yang janggal lagi bagi seseorang (ayah atau ibu) tidak mendapat bagian dari harta peninggalan anaknya. ${ }^{51}$

Lebih lanjut M. Ibrahim mengatakan bahwa hukum waris tidak selamnya harus dilakukan sepenuhnya, maksudnya dalam keadaan tertentu boleh warisa tidak dibagi seperti hukum waris yang ada, meskipun sudah ditetapkan bahagian masing-masing ahli waris dan siapa-siapa saja yang berhak menerima waris, namun jika ahli waris setuju maka bisa saja bagian seorang ahli waris lebih besar daripada bagian ahli waris lainnya, atau misalnya bagian antara anak laki-laki dan anak perempuan, bagian anak laki-laki jelas lebih besar dari pada bagian anak perempuan tapi bisa saja pembagian warisan dibagi sama rata antara anak laki-laki dan anak perempuan jika sama-sama stuju. Begitu jugalah dengan hak waris ayah dan ibu, dalam pemahaman masyarakat Panyabungan Utara sejak dulu yang paling utama mendapat warisan adalah anak dan istri si mayit karena merekalah yang paling membutuhkannya untuk kelangsungna hidup dan pendidikan anaknya. Pendapat ini juga disampaikan oleh Ridwan Nasution. ${ }^{52}$

Selanjutnya Parluhutan Lubis mengatakan:

Pembagian warisan yang ada pada masyarakat Mandailing di Kabupeten Mandailing Natal merupakan kebiasaan yang sudah ada sejak dulu. Anak dan istri si mayit merupakan orang yang paling utama mendapat warisan, karena mereka lebih membutuhkan daripada ayah atau ibu si mayit. Seorang istri yang sudah ditinggal mati suaminya darimana ia bisa mencukupi kebutuhan sehari-hari dan biaya pendidikan anaknya kalau bukan dari peninggalan suaminya. Menurut pendapat saya hal inilah yang menjadi pertimbangan orang-orang dulu kenapa harta warisan diberikan kepada anak dan isti saja, selanjutnya Tuhanpun berpesan kepada manuasia agar jngan meninggalkan generasi yang lemah. Nah atas dasar inilah masyarakat Mandailing di Kabupaten Mandailing Natal terdahulu membuat pembagian warisan seperti yang ada saat sekarang ini. $^{53}$

\section{Faktor-Faktor Yang Melatar Belakangi Pelaksanaan system kewarisan masyarakat Kecamatan Panybungan Utara}

Ketentuan system kewarisan adatmasih diamalkan oleh masyarakat Mandaing Kecamatan Mandailing Natal disebabkan beberapa hal, yaitu:

\section{Warisan Budaya Terun Temurun}

\footnotetext{
${ }^{50}$ M. Taufiq, tokoh masyarakat Panyabungan Utara, wawancara pribadi, Panyabungan Utara, Kabuapaten Mandailing Natal. 2019.

${ }^{51}$ M. Ibrahim, Tokoh Agama masyarakat Panyabungan Utara, wawancara pribadi, Panyabungan Utara, Kabuapaten Mandailing Natal. 2019

${ }^{52}$ Ridwan Nasution, Tokoh Agama Masyarakat Panyabungan Utara, wawancara pribadi, Panyabungan Utara 07 Juni 2019./ M. Ibrahim, Tokoh Agama masyarakat Panyabungan Utara, wawancara pribadi, Panyabungan Utara, Kabuapaten Mandailing Natal. 2019.

53 Parluhutan Lubis, tokoh masyarakat Panyabungan Utara, wawancara pribadi, Panyabungan Utara, Kabuapaten Mandailing Natal. 2019.
} 
Sebagaimana telah dikemukaan sebelumnya bahwa ketentuan system kewarisan adat Mandailing tetap diamalkan masyarakat kecamatan Panyabungan Utara disebabkan kepatuhan mereka terhadap adat yang telah adat sejak dulu. Berikut pernytaan Sogopan: ${ }^{54}$

"Sistem Kewarisan adat yang diamalkan oleh masyarakat Mandaling dan itu sejak ada dari dulu. Ketentuan itu merupakan salah satu warisan para pendahulu kita. Terlepas bagaimana latar belakang timbulnya adat itu yang pasti adat itu diamalkan oleh masyarakat kita khususnya Mandaling. kedudukan adat di Indonesi di akui oleh Undang-Undang .

Begitu juga dengan M. Soleh menjelaskan "bahwa yang merumuskan system kewarisan adat adalah pendahulu adat dan tentunya mereka punya alasan dan aturan itu mengandung gagasan nilai kebaikan dan maslahat bagi masyarakat. orang Mandaling merupakan masyarakat yang taat terhadap adat sebab para tokoh adat dan hatobangon dulu merupakan tauladan dalam masyarakat dan masyarakat Mandaling begitu patuh terhadap ketentuan yang ada karena factor ketauladanan itu, sebab yang lain di Mandaling itu terdapat raja-raja dan dalam system jabatan di Mandaling itu dikenal dalihan Natolu. Semua ketentuan adat itu dilaksanakan oleh raja-raja melalui perangkat-perangkatnya di Dalihan Natolu sehingga masyarakatpun mengikutu tradisi-tradisi itu.

Dari keterangan M. Soleh dan Masirun di atas dapat disimpulakan bahwa pelaksanaan system kewarisan masyarakat Kecamatan Panybungan Utara merupakan salah satu ketentuan adat dalam perkawinan Mandaling.

\section{Pengaruh Ajaran Agama}

Masyarakat Mandailing dengan kebudayaannya telah ada jauh sebelum datangnya Islam, bahkan juga telah ada sebelum agama Hindu memasuki wilayah Mandailing adatistiadat orang Mandailing sudah memiliki tatanan kehidupan, baik itu secara individu maupun secara kelompok (bermasyarakat). Dengan begitu kedudukan hukum adat bagi masyarakat Mandailing merupakan sesuatu yang urgen dan diyakini memiliki nilai yang baik. Sehingga dengan begitu, pelaksanaan hukum adat tidak bisa dihilangkan dari masyarakat Mandailing di Kabupaten Mandailing Natal.

Pada saat berkembangnya Islam di Mandailing dan mayoritas masyarakat Mandailing memeluk agama Islam. Pelaksanaan hukum perkawinan dipengaruhi dua kekuatan hukum yang senantiasa tarik menarik. Di satu sisi adat-istiadat orang Mandailing sudah memiliki tatanan kehidupan, baik itu secara individu maupun secara kelompok (bermasyarakat) karena itu merupakan warisan turun temurun dari para leluhur Mandaiing, di sisi lain agama Islam yang datang kemudian juga membawa tatanan di berbagai aspek kehidupan, yang menuntut ketaatan pula dari para pemeluknya. ${ }^{55}$

Dengan kedatangan Islam itu maka bertemulah dua tatanan kehidupan di dalam masyarakat Mandailing yang masing-masing menuntut kepatuhan dari penganut/pendukungnya, yang membuat adanya persentuhan intens yang saling tarikmenarik antara kepentingan adat-istiadat dan agama. Dalam prakteknya hukum adat dan hukum Islam merupakan dua tatanan yang memiliki kekuatan yang sama, sehingga hukum adat tidak bisa menolak hukum islam dan hukum Islam juga tidak bisa menghilangkan hukum adat sehingga pada akhirnya ditemukan sebuah titik temu dalam pelaksanaan

${ }^{54}$ Sogopan, Kepala Kantor Urusan Agama kecamatan Panyabungan Utara, wawancara pribadi, Kantor KUA kecamatan Panyabungan Utara, Mompang Jae, Kabuapaten Mandailing Natal. 2019

55 Mahmud Lubis, Tokoh Adat Sopo Sorik, wawancara Pribadi, Sopo Sorik. Kabuapaten Mandailing Natal. 2019 
hukum khususnya dalam dalam masalah warisan sehingga muncullah ungkapan ombar adat dohot ugamo pada masyarakat Mandailing. ${ }^{56}$

Masyarakat Mandailing masyarakat yang religius dan dikenal sebagai kota santri, bahkan menurut penulis tidaklah berlebihan jika dikatakan bahwa Mandailing merupakan serambi Mekkahnya Sumatera Utara. Sebelum Islam masuk ke Mandailing, masyarakat Mandailing dahulu memeluk sistem kepercayaan lama (animisme) yang disebut $S i$ Pelebegu, kepercayaan Sipelebegu adalah menyembah roh-roh dari para leluhur (nenek moyang) mereka yang disebut Begu. Pada saat masyarakat Mandailing pelaksanaan adat dan budaya merupakan bagian ritual dari kepercayaan Sipelebegu. ${ }^{57}$ Namun dalam perkembangannya kemudian, seiring dengan masuknya agama Islam ke Mandailing dan mayoritas telah menjadi pemeluknya yang taat, para ulama Islam terus berusaha untuk mengikis habis kepercayaan animisme Si Pelebegu.Dengan terkikisnya sistem kepercayaan Si Pelebegu, pelaksanaan hukum perkawinan masyarakat Mandailing diwarnai dengan nilai-nilai keislaman.

\section{Ketauladanan Hatobangon dan Malim Kampung}

Bagi masyarakat Mandailing di Kabupaten Mandailing Natal, ulama (malim kampung) merupakan pewaris nabi dan memiliki peranan penting dalam mengawal perkembangan hukum di Mandailing.Bagi orang Mandailing fatwa atau pendapat seorang 'alim merupakan keputusan penentu yang tidak perlu dibandingkan lagi. Pada bagian ini, peneliti ingin mengutip Basyral Hamidy yang dalam salah satu artikelnya mengutip salah satu artikel Mohammad Natsir yang berjudul, Kedudukan Ulama2 Dalam Masyarakat yang dimuat dalam Pandji Islam edisi Juni 1939 dan diterbitkan kembali di dalam kumpulan tulisannya yang berjudul, Capita Selecta, 1954, halaman 133-138. Mohammad Natsir antara lain menulis:

“...masjarakat Islam sudah mempunjai pemimpin dan pengandjur mereka dalam hal 2 jang berhubungan dengan keagamaan dan penghidupan mereka sehari2. Dalam desa2 dan kampung2 Guru atau Sjech, Angku Sieh di Minangkabau atau Kiai di Djawa dan bermatjam2 nama panggilan pada beberapa tempat, adalah tempat rakjat bertanja, tempat memulangkan sesuatu urusan, tempat meminta nasihat dan fatwa, tempat mereka menaruhkan kepertjajaan.

Bagi mereka, fatwa seorang alim jang mereka pertjajai berarti suatu katakeputusan, jang tidak dapat dan tak perlu dibandingkan lagi.Seringkali terbukti, bagaimana susahnja bagi pemerintah negeri mendjalankan satu urusan, bilamana tidak disetudjui oleh alim-ulama jang ada dalam satu daerah.

Sebaliknja pun begitu pula. Beruntunglah salah satu masjarakat, bila mempunjai seorang alim, sebagai pemimpin ruhani jang tahu dan insaf akan tanggungannja sebagai penganjur dan penundjuk djalan. Aman dan makmurlah salah satu daerah bilamana pegawai2 pemerintah disitu tahu menghargakan kedudukan alim ulama ang ada di daerah itu.

Ulama bukanlah pemimpin yang dipilih dengan suara terbanjak, bukan jang diangkat oleh persidangan kongres. Akan tetapi kedudukan mereka dalam kebatinan rakjat yang mereka pimpin, djauh lebih teguh dan tjuci dari pergerakan jang berorganisasi, atau pegawai pemerintah jang manapun djuga.

Ulama ialah waris nabi-nabi, pemimpin umat jang mendapat pengakuan agama.Dalam mentjapai kemadjuan rakjat umumnja, "korsp" ulama jang

56 Sutan Kumala, Tokoh Adat kecamatan Ulu Pungkut, wawancara pribadi, Ulu Pungkut Kabuapaten Mandailing Natal. 2019

${ }^{57}$ Imaran, Tokoh Adat desa Jambur Padang matinggi (Wawancara pribadi, Jambur Padang Matinggi. Kabuapaten Mandailing Natal. 2019. 
bertebaran itu sekali2 tak boleh diabaikan, baik oleh pegawai pemerintah, ataupun oleh pengandjur2 pergerakan kita.Mereka itu adalah satu factor jang penting dalam kerdja pertjerdasan rakjat pada umumnja. Koordinasi pekerdjaan antara ulama2, pegawai2 pemerintah dan pemuka2 pergerakan social dan politik, tidak akan diperdapatm bilamana pihak ulama tidak berkehendak turut memperhatikan dan menurutkan gelora zaman, ... "58

Kutipan panjang di atas menunjukkan arti penting kedudukan ulama bukan saja dalam relasinya dengan pemerintah tetapi lebih penting dari itu dalam hubungannya dengan ummatnya.Dalam konteks relasi ganda itulah para ulama harus mampu memposisikan dirinya secara tepat. Pada saat yang sama, ulama juga dihadapkan dengan persoalan yang tidak kalah peliknya, perubahan sosial yang tidak pernah bisa dibendung apa lagi dihentikan.

Mencermati peran ulama dalam mengembangkan hukum Islam di Mandailing, tidaklah berlebihan jika dikatakan bahwa Syekh Musthafa Husein adalah simpul Islam di Mandailing. ${ }^{59}$ Nama Syekh Musthafa Husein dan Musthafawiyahnya adalah puncak dari perkembangan Islam di Mandailing. Bahkan dari Musthafawiyahlah Islam terus berkembang ke berbagai macam wilayah di Sumatera dan sekitarnya. Ulama-ulama masa lalu juga respon terhadap perkembangan zaman. Hal ini terlihat pada saat mereka mulai merespon model-model pendidikan modern dan menerapkannya dalam pendidikan Islam. Hanya saja yang membedakan respon tersebut adalah masalah waktu atau temponya saja.

Ada ulama yang sangat cepat merespon perubahan zaman sepanjang tidak bertentangan dengan nilai-nilai syari'at. Namun ada juga ulama yang memberikan respon yang sedikit lambat, walaupun pada akhirnya ia tak mampu menolak perubahan tersebut. Ulama pada masa lalu juga memiliki kesadaran akan alat perjuangan. Pada gilirannya mereka memiliki satu kesadaran baru bahwa perjuangan sesungguhnya membutuhkan satu alat yang disebut organisasi. Kesadaran berorganisasi sebagai alat perjuangan tampak pada kelahiran NU di Tapanuli Selatan. Semuanya dilandasi pada satu semangat bagaimana menghimpun kekuatan untuk mewujudkan sebuah mimpi bersama, hasanah fi al-dunya dan hasanah fi al-akhirat.

Pengajian-pengajian dari masjid ke masjid atau dari kampung ke kampung yang dilakukan para ulama Mandailing sebagai usaha untuk mengembangkan dan menanamkan nilai-nilai Islam pada masyarakat Mandailing membuahkan hasil, sehingga dengan begitu pelaksanaan adat perkawianan dan budaya di kalangan masyarakat Mandailing dengan sendirinya dimasuki nilai-nilai Islam sehingga adat tetap dilaksanakan karena sudah diperbaiki dan dimasuki nilai-nilai Islam.

Tentang ketauladanan baik hatobangon dan malim kamung dijelaskan oleh Imran bahwa ketentuan waris secara adatmasih diamalkan oleh masyarakat. Lebih lanjut Imaran menjelaskan masyarakat sekarang mengamalkan ketentuan warisan secara adat merupakan cerminan dari jati diri masyarakat yang taat terhadap peraturan dan mencontoh ketauladanan. Para pendahulu adat baik hatobangon ataupun malim kampung sangat mematuhi ketentuan yang ada baik ketentuan agama maupn adat sehingga dengan

${ }^{58}$ Basyral Hamidy Harahap, Ulama dan Perubahan Sosial, h. 2-3

59 Syekh Musthafa Husein adalah salah seorang ulama terkemuka di Sumatera Utara yang meninggalkan karya bangunan keislaman monumental pesantren Musthafawiyah yang sudah berusia 112 tahun, pesantren Musthafawiyah melalui para alim ulama dan murid-muridnya merupakan orang-orang yang menduduki posisi strategis terhadap perkembangan Islam di Mandailing. Sebelum Syekh Musthafa Husein hadir di Mandailing, ada beberapa ulama yang telah mengawal keberadaan Islam di Mandailing. 
ketauadanan yang dimiliki oleh hatobangon dan malim kampong masyarakatpun mencontoh dan mentaati ketentuan yang ada. ${ }^{60}$

\section{E. Analisis}

1. Bagian Ayah dan Ibu dalam Sistem Kewarisan Masyarakat Mandailing di Kabupaten Mandailing Natal

Dalam sistem kewarisan Islam, baik dalam fikih klasik maupun Kompilasi Hukum Islam ayah dan ibu merupakan ahli waris yang berhak mendapat warisan dan tidak bisa dihijab oleh ahli waris yang lain baik itu anak ataupun istri. Hal ini difahami dari Firman Allah Swt yang artinya: Allah mensyari'atkan bagimu tentang (pembagian pusaka untuk) anak-anakmu. Yaitu : bahagian seorang anak lelaki sama dengan bagahian dua orang anak perempuan; dan jika anak itu semuanya perempuan lebih dari dua, Maka bagi mereka dua pertiga dari harta yang ditinggalkan; jika anak perempuan itu seorang saja, Maka ia memperoleh separo harta. dan untuk dua orang ibu-bapa, bagi masingmasingnya seperenam dari harta yang ditinggalkan, jika yang meninggal itu mempunyai anak; jika orang yang meninggal tidak mempunyai anak dan ia diwarisi oleh ibu-bapanya (saja), Maka ibunya mendapat sepertiga; jika yang meninggal itu mempunyai beberapa saudara, Maka ibunya mendapat seperenam. (Pembagian-pembagian tersebut di atas) sesudah dipenuhi wasiat yang ia buat atau (dan) sesudah dibayar hutangnya. (Tentang) orang tuamu dan anak-anakmu, kamu tidak mengetahui siapa di antara mereka yang lebih dekat (banyak) manfaatnya bagimu. ini adalah ketetapan dari Allah. Sesungguhnya Allah Maha mengetahui lagi Maha Bijaksana.

Dari ayat di atas dapat dipahami bahwa ayah dan ibu tetap mendapat waris baik ada anak maupun tidak. Dengan kata lain ayah dan ibu merupakan ahli waris yang tidak bisa dihalang dalam keadaan apapun kecuali jika ayah atau ibu melakukan salah satu pengahalang mewarisi seperti membunuh pewaris datau berlainan agama.

Kedudukan waris ayah dan ibu pada masyarakat Mandailing di Kabupaten Mandailing Natal bisa terhalang oleh anak. Akan tetapi jika si mayit tidak meninggalkan anak maka ahli waris yang lain tetap mendapat bagian sesuai dengan bagian yang telah ditentukan oleh syara'. Hal ini tentu berlawanan dengan kewarisan hukum Islam baik dalam fiqih klasik maupun Kompilasi Hukum Islam.

Masyarakat masyarakat Mandailing di Kabupaten Mandailing Natalmerupakan masyarakat yang religius dan tentunya mereka mengetahui ajaran agama meskipun tidak secara keseluruhan. Dalam pemahaman masyarakat masyarakat Mandailing di Kabupaten Mandailing Natalanak dan istri merupakan orang yang lebih utama mendapat warisan. Pemahaman masyarakat masyarakat Mandailing di Kabupaten Mandailing Natalseperti ini mencul atas dasar pertimbangan kelangsungan hidup istri dan pendidikan anak si mayit sehingga dengan pertimbangan tersebut harta warisan menjadi hak anak dan istri si mayit.

Pemahaman dan pertimbangan masyarakat masyarakat Mandailing di Kabupaten Mandailing Natalbisa diterima akal. Karena jika ahli semua ahli waris setuju maka harta warisan boleh dibagi sama rata setelah masing-masing ahli waris mengetahui bagiannya masing-masing. Sama halnya dengan kedudukan waris ayah/ ibu dalam masyarakat Panyabungan Utara, jika ayah/ibu ridha terhadap haknya sebagai pewaris anaknya dan bagiannya menjadi melik cucu (anak simayit) dan menantunya (istri si mayit) maka hal ini beloh dilakukan.

60 Imaran Nasution, tokoh Adat Jambur Padang Matinggi, Wawancara Pribadi, Jambur padang Matinggi, Kabuapaten Mandailing Natal. 2019. 


\section{F. Penutup}

Dari analisis terhadap data lapangan dan ketentuan Hukum Islam yang berkaitan dengan kewarisan ayah dan ibu pada masyarakat Mandailing di Kabupaten Mandailing Natal. Hak kewarisan ayah dan ibu walaupun secara hukum Islam (ilmu faraid) mendapatkan hak kewarisan, namun pada praktiknya dilapangan di masyarakat Mandailing Kabupaten Mandailing Natal, ayah dan ibu tidak diberikan harta kewarisan sesuai dengan besaran hak yang diterimanya. Hal ini disebabkan pertimbangan bagi kelangsungan hidup istri dan anak si mayit, seperti kebutuhan akan pendidikan dan sebagainya sehingga dengan pertimbangan tersebut harta warisan menjadi hak anak dan istri si mayit, sehingga ayah dan ibu merelakan kedudukannnya sebagai ahli waris dan hak kepemilikan harta warisan dari anaknya yang telah meninggal dunia. Maka berdasarkan hal tersebut, sesungguhnya semangat pelaksanaan hukum masyarakat Mandailing di Kabupaten Mandailing Natal khususnya dibidang waris adalah semangat kemashlahatan untuk keberlangsungan hidup cucunya.

\section{DAFTAR PUSTAKA}

\section{BUKU}

A. Sukris Sarmadis, Transendensi Keadilan Hukum Waris Islam Transformatif (Jakarta: Raja Grafindo Persada, 1997).

Abdul Rahman Yusuf Jalal, al-Khulashah al- Wafiyah fi al- Mawaris al- Islamiyah, (Kairo: Dar al- Ta’lifi, 1969).

Ahamd Rofiq, Fiqh Mawaris (Jakarta: Raja Grafindo, 1995).

Ahmad Rafiq, MA. Fiqh Mawaris, (Jakarta: Raja Grafindo Persada, 1995).

Departemen Agaman RI, al-Qur'an ddan Terjemahannya, (Semarang: Toha Putra, 1989).

Dewan Redaksi Ensiklopedi Islam, Ensiklopedi Islam, Jilid 3, (Jakarta: PT. Ikhtiar Baru Van Hoeve, 1993).

Eman Suparman Hukum waris Indonesia ( Bandung: PT Refika Aditama, 2007).

Fatchur Rahman, Ilmu Waris, (Bandung : PT al- Ma'arif, 1981).

Hasbi Ash Shiddieqy, Fiqh Mawaris (Semarang: Rineka Cipta, 2011).

Louis Ma'lup, al-Munjid Fi al-Lughah wa al- 'Alam,(Bairut: al- Syarghiyah, 1973).

M. Idris Ramulyo, Hukum Kewarisan Islam, Studi kasus Perbandingan Ajaran Syafi'I (Patrilinial), Hazairin (bilateral) dan Praktek di Peradilan Agama ( Jakarta: Grafikatama, 1987). 
Muhammad bin Idris al- Syafi'I, al-Umm, (Mesir: Dar al-Syu’bi, Juz IV, t,t).

Roihan A. Rasyid, dalam Departemen Agama, Penyelesaian Perkara Umat Islam di Indonesia, dalam Mimbar Umum, No. 9 thn 1993 (Jakarta: al-Hikmah, 1993).

Sayuti Thalib, Pembaharuan Hukum Islam di Indonesia (Jakarta: UI Press, 1981).

Sayyid Sabiq, Fiqh al- Sunnah, (Bairut: Dar al-Fikr, 1981, Jilid III).

T.M. Hasbi Ash-Shidieqy. Fiqih Mawaris (Hukum-hukum Warisan dalam Syari'at Islam),(Jakarta: Bulan Bintang, 1967),

WJS. Purwadarta, Kamus Besar Bahasa Indonesia, (Jakarta: PN. Balai Pustaka, 1983).

\section{Webset:}

http://www.republika.co.id/berita/dunia-islam/hikmah/13/08/24/ms0foc-melacak-sejarahhukum-waris

\section{Wawancara:}

Abdus Samad, BKM Masjid Nurul Muttaqin Panyabungan Utara, wawancara Pribadi, Panyabungan Utara Kabuapaten Mandailing Natal. 2019

Ikmal shadiqqin, tokoh Agama Panyabungan Utara, wawancara pribadi, Panyabungan Utara Kabuapaten Mandailing Natal. 2019

Imaran Nasution, tokoh Adat Jambur Padang Matinggi, Wawancara Pribadi, Jambur padang Matinggi, Kabuapaten Mandailing Natal. 2019.

Imaran, Tokoh Adat desa Jambur Padang matinggi (Wawancara pribadi, Jambur Padang Matinggi. Kabuapaten Mandailing Natal. 2019.

M. Ibrahim, Tokoh Agama masyarakat Panyabungan Utara, wawancara pribadi, Panyabungan Utara, Kabuapaten Mandailing Natal. 2019

M. Taufiq, tokoh masyarakat Panyabungan Utara, wawancara pribadi, Panyabungan Utara, Kabuapaten Mandailing Natal. 2019.

Mahmud Lubis, Tokoh Adat Sopo Sorik, wawancara Pribadi, Sopo Sorik. Kabuapaten Mandailing Natal. 2019

Mawardi Lubis, tokoh masyarakat, wawancara pribadi, Panyabungan Utara, Kabuapaten Mandailing Natal. 2019 
Parluhutan Lubis, tokoh masyarakat Panyabungan Utara, wawancara pribadi, Panyabungan Utara, Kabuapaten Mandailing Natal. 2019.

Ridwan Nasution, Tokoh Agama Masyarakat Panyabungan Utara, wawancara pribadi, Panyabungan Utara 07 Juni 2019./ M. Ibrahim, Tokoh Agama masyarakat Panyabungan Utara, wawancara pribadi, Panyabungan Utara, Kabuapaten Mandailing Natal. 2019.

Sogopan, Kepala Kantor Urusan Agama kecamatan Panyabungan Utara, wawancara pribadi, Kantor KUA kecamatan Panyabungan Utara, Mompang Jae, Kabuapaten Mandailing Natal. 2019

Sutan Kumala, Tokoh Adat kecamatan Ulu Pungkut, wawancara pribadi, Ulu Pungkut Kabuapaten Mandailing Natal. 2019 